\title{
DESENCAIXAR PARA DESCOLONIZAR: aprender a aprender COM os povos originários da América Latina ${ }^{1}$
}

\author{
DESENCAJAR PARA DESCOLONIZAR: \\ aprender a aprender CON los pueblos originários de America Latina
}

\author{
DISASSEMBLING TO DECOLONIZE: \\ learning to learn WITH the originating peoples of Latin America
}

\section{Lígia Marina de Almeida}

\begin{abstract}
RESUMO: Este artigo busca apresentar uma experiência artístico-pedagógica, no campo das artes cênicas, desenvolvida na Escola Estadual Indígena de Ensino Médio Pascoal Leite Dias (Terra Indígena Terena Limão Verde - Aquidauana/MS - 2016) como possível modelo de ação, a ser refuncionalizado, para artistas-pedagogos em artes cênicas interessades em dialogar com a Lei 11.645/2008 que institui a obrigatoriedade do ensino de História e Cultura Indígena e Afro-Brasileira nas escolas de Ensino Fundamental e Médio de todo país.
\end{abstract}

PALAVRAS-CHAVE: artes cênicas, Lei 11.645/2008, pedagogia, povos indígenas

RESUMEN: En este artículo se busca presentar una experiencia artístico-pedagógica, en el campo de las artes escénicas, desarrollada en la Escuela Estadual Indígena Pascoal Leite Dias (Tierra Indígena Terena Limão Verde - Aquidauana/MS - 2016) como posible modelo de acción, a ser refuncionalizado, para los artistas-pedagogos en artes escénicas interesades en dialogar con la Ley 11.645/2008 que instituye la obligatoriedad de la enseñanza de Historia y Cultura Indígena y Afro-Brasileña en las escuelas de enseñanza básica de todo país.

PALABRAS-CLAVE: artes escénicas, Ley 11.645/2008, pedagogía, pueblos indígenas

\begin{abstract}
This article aims to be an artistic-pedagogical experience, in the field of scenic arts, developed in the Indigenous School of Terena Limão Verde Land (Aquidauana/MS - 2016). Refuncionalised, for artists-pedagogics in performing arts in the education with the Law 11.645/2008 that institution in the lecturer of education and Indigenous and Afro-Brazilian in schools of Elementary School and Medium in the country.
\end{abstract}

KEYWORDS: Law 11.645/2008, peoples of Latin America, pedagogy, performing arts

\footnotetext{
${ }^{1}$ Esse texto, cada linha, é fruto da aprendizagem-interlocução com Casé Angatú Xukurú Tupinambá, Jerá Poty Guarani-Mbya e João Francisco Branco, aos quais agradeço profundamente. No entanto, a tarefa (e risco!) desta articulação e "tradução" de aprendizagens seja de minha inteira responsabilidade. 2 Provocadora de processos psicomágicos e pesquisadora indisciplinar. Doutoranda do Programa de PósGraduação em Teatro da Universidade do Estado de Santa Catarina com a pesquisa em andamento intitulada $A B C$ da luta dos povos originários do Brasil: performances, pedagogias, propagandas $e$ (imagens) políticas pela descolonização social sob orientação da Profa. Dra. Fátima Costa de Lima. (caso queira e possa colaborar financeiramente com a luta dos povos originários, me escreva!) limarina70@gmail.com. Bolsista PROMOP/UDESC.
} 
Sobre o homem branco: "O mundo deles é quadrado, eles moram em casas que parecem caixas, trabalham dentro de outras caixas, e para irem de uma caixa à outra, entram em caixas que andam. Eles vêem tudo separado, porque são o Povo das Caixas. (frase de um pajé do povo Kaingang, recolhida por Lúcia Fernanda Kaingang - extraído da página pessoal da rede social Facebook de Oráculo Naine Terena)

El mundo que queremos es uno donde quepan muchos mundos. La patria que construimos es una donde quepan todos los pueblos y sus lenguas, que todos los pasos la caminen, que todos la rían, que la amanezcan todos. (extraído do verbete da enciclopédia virtual Wikipédia sobre) Subcomandante do Exército Zapatista de Libertação Nacional Marcos

Museu de Arte de São Paulo (MASP), uma das maiores caixas colecionadoras de objetos... de arte (localizada, não coincidentemente, no centro financeiro de uma das maiores cidades do mundo: a cidade de São Paulo ou em língua tupi, Piratininga). E se, segundo o filósofo alemão Walter Banjamin, "não há um documento de cultura que não seja, ao mesmo tempo, um documento da barbárie” (BENJAMIN, 1987, p. 225), o que representa tal museu, se transformarmos ele também numa iconografia?

No entanto, há quem se esforce em furar caixas para a circulação de (novos) ares, em empilhar as caixas de diferentes formas, em dar a vê-las de maneiras diferentes, de dispô-las em arranjos ainda não feitos e de "escovar a história a contrapelo" (como também nos ensina Walter Benjamin). Creio que o que aconteceu no MASP Professores: Encontros sobre arte, educação e esfera pública com o tema Cultura e educação indígena no dia 15 de julho de 2017, sob curadoria de Lucas Oliveira, é um desses importantes esforços.

Fui convidada para fazer um dos relatos críticos deste encontro. Creio que o motivo do convite se deva ao fato de eu ser uma trabalhadora da cultura e da educação e que desde 2013 empreendo esforços para aprender com os povos originários desse lugar que convencionou-se chamar Brasil (não sem muita violência) como fazer a luta anti-colonial, anti-capitalista e anti-estatal, e como fazer a "arte falar"3 sobre esses temas junto com as artes cênicas.

\footnotetext{
3 "A vida em confinamento é viver sem arte, viver sem sonho, viver sem a terra. A vida em confinamento é fazer viver sem vida, a gente tem que fazer a arte falar, ser artista é fazer a arte falar e a vida em confinamento é matar a arte dentro da gente, é matar a arte dentro da vida do povo kaiowá. Então, viver a arte, fazer arte falar é ser livre e não viver em confinamento. Estar em confinamento: o que é a vida sem sorrir, o que é a vida sem viver, o que é a vida sem a arte de viver a terra, de viver na terra, na terra tradicional do povo kaiowá-guarani. Então, essa forma que nós estamos vendo e nos sentimos muito emocionados porque isso é viver em confinamento, isso é confinamento. Então agradecemos a vocês essa oportunidade, essa pequena oportunidade de ouvir um pouco do nosso canto, do nosso sorriso, que ainda resta para o povo kaiowá-guarani. A gente agradece a todos vocês: e vivam essa arte, todos os
} 
Assim, estive presente, num sábado frio, em plenas férias escolares, num encontro que reuniu quase duzentos professores da rede básica de ensino em torno deste tema: o que levou, mesmo nessas circunstâncias, todas essas pessoas a estarem lá? Creio que por três principais motivos.

O primeiro motivo seria uma espécie de resposta presentificada ao chamado que vários povos originários vem fazendo através de diversas ações dirigidas à nãoindígenas, para refletirem e se posicionarem em relação às lutas que estes povos vem travando a 517 anos contra a forma sócio-econômica colonial/capitalista/catequética. As pautas dessas lutas, que na urgência da hora podem ser sintetizadas na insígnia (e hashtag) \#DemarcaçãoJá (das terras indígenas tanto as homologadas quanto as em processo de homologação pelo Governo Federal quanto as tantas outras que o Estado brasileiro insiste em não reconhecer), envolvem uma outra relação com a terra/natureza: nela, o ser é também a própria terra/natureza, determinando uma relação de (auto) preservação da mesma, de forma antagônica ao que estamos vivendo hoje - rumo ao colapso da noção de vida sob a Terra.

Podemos ver tal chamado, por exemplo, no manifesto Porque fechamos a bandeirantes? que é parte da ação realizada em 26 de Setembro de 2013, anunciando a Semana Nacional de Mobilização Indígena daquele ano. Os Guarani Mbya de São Paulo organizados na Comissão Guarani Yvyrupa bloquearam a Rodovia dos Bandeirantes - que atravessa suas terras - exigindo o reconhecimento da mesma:

Fizemos isso para vocês, brancos, saberem que nós existimos (...) Convocamos todos os movimentos sociais e todas as pessoas que são contra a devastação da natureza e são contra a concentração da riqueza do país na mão de poucos latifundiários... Vamos às ruas (...)!'(COMISSÃO GUARANI YVYRUPA, 2013)

O segundo motivo seria por conta da implementação da Lei 11.645/2008 que instaura o ensino da História e Cultura Indígena e Afro-brasileira nas escolas de Ensino Fundamental e Médio de todo país, lei esta fruto da luta de vários povos originários e do movimento negro e quilombola no país. No entanto tal lei não se aplica

artistas. Vocês são artistas que trazem para o mundo ver a tristeza daqueles que não podem falar, o choro daqueles que não podem ser ouvidos, a voz daqueles que já não existem mais, que tombaram na luta pela terra, tombaram na luta por um pedacinho de teto, tombaram na luta pela vida mesmo, em todos os lugares deste mundo, vocês são a voz, a voz do povo é o artista. Agradeço por podermos vir e por poder estar aqui com vocês." Liderança guarani-kaiowá Valdelice Verón In BAROUCKI, Wilson. $A$ palaura que age - medida performativa \#1. 2013. Disponível em: $<$ https://www.youtube.com/watch?v=Lar_LtmmVeQ>. Acesso em: 18/07/16. 
ao Ensino Superior, ou seja, como os profissionais da educação podem trabalhar tais temáticas sendo que não fomos "formados" para isso? Não obstante também fomos muito mal-informados durante toda nossa vida escolar sobre essas históriaS e culturaS. Segundo o Prof. Dr. Casé Angatú Xukurú Tupinambá, em seu texto "Histórias e culturas indígenas"- alguns desafios no ensino e na aplicação da lei 11.645/2008: de qual história e cultura indigena estamos mesmo falando?:

Existem educadores que assinalam para a permanência do imaginário, apontando "os indígenas apenas como vítimas, sendo exterminados e/ou integrados à sociedade nacional". Desse olhar decorre a idealização dos "índios como os bons selvagens do século XVI". Dele também deriva a leitura de que os indígenas não "se adaptaram à sociedade, sendo substituídos pela 'mão de obra' escrava negra e, posteriormente, pelos imigrantes europeus, existindo índios somente na floresta amazônica". Por fim, aparece a constatação da falta de formação acadêmica durante a graduação sobre Histórias e Culturas Indígenas levando muitos a indagarem: "o que devo mesmo lecionar sobre os Povos Indígenas?"

(...)

Aventamos: talvez, só tardiamente se tenha observado que faltava uma especificação sobre esse conteúdo na formação escolar brasileira por tratar-se de uma discussão que também envolve atualmente o direito originário a terra. O direito dos Povos Originários, por sua vez, tem gerado conflitos em diferentes regiões brasileiras e a morte de indígenas, como observamos anteriormente pelos dados do Conselho Indigenista Missionário - Cimi (2015). Acreditamos que estes também constituem parte dos motivos relativos às dificuldades para a implantação da Lei 11.645/2008. (ANGATÚ, 2015, p. 198)

O terceiro motivo estaria centrado na acertada escolha plural dos debatedoresprovocadores-palestrantes convidados ao encontro: a antropóloga Clarice Cohn que abordou algumas experiências de como alguns povos originários, dentre eles os Xikrin, Guarani Mbyá e Tupinambá de Olivença, subvertem a arquitetura e pedagogia escolar "tradicional"; o ex-professor da rede de ensino do Estado de São Paulo João Branco que desenvolve e partilha pesquisas acerca da experiência de mobilizações e lutas dos professores da região de Oaxaca no México e de propostas indígenas de educação nesse país e a professora e liderança Guarani Mbya da auto-demarcada (e declarada porém não demarcada pelo Governo Federal) Terra Indígena Tenondé Porã, Jerá Poty, também integrante da Comissão Guarani Yvyrupa, que nos narrou, dentre outros profundos aprendizados, o porque optou pela saída da educação escolar formal (mesmo sendo professora de uma escola indígena) a favor de outros processos educacionais não-escolares e mais conectados à cosmologia guarani. Voltarei neste texto a comentar sobre um dos aprendizados que creio que todos nós presentes neste encontro levamos conosco da palavra-ação de Jerá Poty. 
Depois deste primeiro momento, nós professores fomos convidados a nos dividir em três grupos de trabalho, para aprofundar algumas questões levantadas durante a manhã, coordenado cada qual por um dos debatedores-provocadores-palestrantes. Assim, tinha como tarefa acompanhar o grupo de trabalho acerca das questões trazidas por João Branco.

Numa primeira parte deste grupo de trabalho João, com sua metodologia de ensino-aprendizagem libertária, nos trouxe vídeos, referências teóricas e imagens de uma das maiores insurgências populares da América Latina, fruto da luta docente e indígena no sul do México: a Comuna de Oaxaca (2006). João resume essa luta na abertura de sua dissertação de mestrado intitulada Movimento Docente, Insurreição Popular e Propostas Coletivas de Educação Alternativa em Oaxaca:

uma onda de protestos populares levou à tomada da capital do Estado pelos manifestantes, à dissolução do poder político e à violenta ação de desocupação imposta pelo Governo Federal do México. Segundo relatos, o papel que os professores da rede pública de Oaxaca, por meio da Seção XXII do Sindicato Nacional dos Trabalhadores da Educação do México (SNTE,) desempenharam antes e durante a revolta popular de 2006 foi fundamental para nascer a Comuna de Oaxaca. (BRANCO, 2015,p.9)

Aquela experiência auto-gestionada de educação e de luta por melhores condições de ensino-aprendizagem-vida, alternativa aos modelos neo-liberais propostas pelo Estado do México (aliada ao capital financeiro mundial, como acontece em toda América Latina), e aliada às cosmovisões de diversos povos originários da região de Oaxaca, via organização docente em modelos mais parecidos com movimentos sociais do que sindicatos fez com que, rapidamente, durante o debate que se seguiu, alguns professores ali presentes trouxessem à baila de nossa discussão, de forma elogiosa, a onda de ocupações de escolas públicas liderada pelo corpo discente de tais instituições no estado de São Paulo em 2015 contra uma proposta de reorganização das mesmas (pra pior!) pelo governador (bandeirante moderno!) Geraldo Alckmin.

E em seguida a questão (frente aos dois modelos de ação debatidos professores de Oaxaca e secundaristas de São Paulo): o que fazer e como fazer para transformar as atuais condições de educação e de vida num sentido contrário ao que se vem desenhando pela atual conformação política-econômica de Estado e desta representação política que está no poder e que está, de forma galopante, sucateando a educação pública no país (PEC 241, projeto Escola sem Partido, Lei da Mordaça, 
Reforma do Ensino Médio, corte da verba de pesquisa, etc.) enquanto categoria docente de trabalhadores?

Jerá Poty, na finalização de sua palavra-ação nos diz que se o professor nãoindígena, corroborando com a Lei 11.645/2008, quer trabalhar com as histórias e culturas indígenas em seus processos pedagógicos, que o fizesse, enquanto sugestão, mirando para as histórias das lutas dos povos originários durante esses 517 anos. Pelo que lutam? COMO lutam? Aonde lutam? Quais os discursos e materiais áudio-literovisuais produzidos por esses povos acerca de suas lutas que estão a disposição? É possível contatar uma pessoa auto-declarada indígena para que ela mesma possa ensinar e propor vivências sobre suas visões de mundo, do tempo, da história e da cultura de próprio corpo e alma?

Talvez esta possa ser a inspiração que nós, "povo da mercadoria" ${ }^{4}$, precisemos para que possamos empilhar nossas caixas em forma de barricadas, por outra pedagogia possível, por outros mundos possíveis.

E se os povos originários da América Latina, já são o outro mundo possível (como o Prof. Casé Angatú Xukurú Tupinambá sempre nos lembra a todos) (r)eXistindo nesse momento histórico, lutando pela sobrevivência de todos nós, creio que é necessário, ao menos, apoiar (de diversas e diferentes formas possíveis) suas lutas e atender aos seus chamados.

Como atender a um chamado como este, por exemplo, junto com as artes cênicas e a pedagogia?

Há uma história triste. Uma história de dominação social em que a aliança entre "teatro", "pedagogia" está intimamente atrelada. Digamos que a fundação do teatro brasileiro se dá justamente no ato de dominar, físico e culturalmente os povos originários da região que convencionou-se chamar (não sem muita violência) de Brasil. Assim os jesuítas, funcionários da multinacional Companhia de Jesus, a serviço da colonização/civilização/catequização, utilizam o teatro como expediente metodológico

\footnotetext{
4 Segundo David Kopenawa Yanomami: "os brancos dizem: "somos os únicos a nos mostrar tão engenhosos! Somos realmente o povo da mercadoria! Poderemos ser cada vez mais numerosos sem jamais passar necessidades!"Abriu-se, assim, um ímpeto de expansão; "seu pensamento se enfumaçou e a noite o invadiu. Ele se fechou às outras coisas. Foi com estas palavras da mercadoria que os brancos começaram a cortar todas as árvores, maltratar a terra e a sujar as águas.” In TIBLE, 2013, p.432.
} 
para aplicação de sua dramaturgia tão bem desenvolvida no livro bíblico: a liturgia do apocalipse, a morte do corpo e da cultura dos Outros ${ }^{5}$.

E porque será que a forma teatral tão bem se encaixa enquanto metodologia civilizatória?6 A resposta possa estar em sua fundação: os gregos inventaram a forma teatral justamente para isso, para disciplinar o corpo de sua plateia, o corpo daqueles "que só veem"7 e expurgam suas emoções no ato de ver UMA REPRESENTAÇÃO de suas próprias emoções. Ao cidadão grego, assim, só restaria se ver representados no teatro e na vida política e jamais fazer justiça com as próprias mãos como o faziam nas suas organizações sociais chamadas genos: agora a justiça seria Estatizada.

Teria o teatro, assim, salvação? Assim sendo, teatro é o melhor campo para tratar e acionar a luta pelo que lutam os povos originários? Ou por outra, o teatro pode ser encarado como instância formal una? E as disputas históricas sobre o próprio teatro?

Falamos de teatro, mas sabemos que o campo das artes cênicas é mais amplo, inclusive ele, tentando abarcar processos rituais e/ou performativos e/ou outros que tentam se opor formalmente aos processos representacionais, no entanto, tais processos, em sua forma/conteúdo/circulação/modo de produção também buscam o que estamos chamando hoje de descolonização?

\footnotetext{
5 Não me aterei aqui a desenvolver tais ideias apenas gostaria de apontar que embora os fins da atuação dos jesuítas entre os povos originários tenham sentido único, o da dominação e coerção de seus corpos, seus processos para tais fins podemos nominar como contraditórios. Sabemos das diversas ações destes jesuítas em "proteger" os povos originários de gente sem nenhuma contradição em seus objetivos com eles, dentre outros episódios coloniais complexos. Objetivo, durante o percurso de meu doutoramento, pesquisar e desenvolver ideias acerca deste tema de forma mais aprofundada.

6 Vale ressaltar que os jesuítas propunham, em seus autos, a mistura de línguas, entre línguas originárias, português e castelhano, inclusive à revelia de seus patrões que monitoravam tudo da metrópole além-mar. Vários foram os jesuítas que sofreram processos e perderam seus empregos por não acatar o latim como língua oficial dentre outros. Aliás, dizem parte dos pesquisadores do pecado original colonial que foi graças aos jesuítas que o tupi sobreviveu, inclusive sendo língua oficial da região paulista até o século XIX. Para mim o tupi sobreviveu por reXistência destes povos originários ao projeto colonial. Eles fizeram os jesuítas a ter que modificar suas formas de dominação, aprendendo a língua tupi, e encenando seus autos (com "atores" indígenas) também em tupi, caso quisessem cumprir seus sórdidos fins: de entrar e usar a cultura do Outro para destruí-la. Nisso, os jesuítas também tiveram que modificar a própria forma teatral que traziam em suas bagagens tendo que compor a forma representacional com formas rituais dos povos originários, formando assim uma "encenação", uma nova forma teatral: o teatro jesuítico.

${ }^{7}$ A etimologia da palavra teatro remete a theatron que significa, "lugar de onde se vê".
} 
Nesse último sentido, gostaria de compartilhar algumas tentativas de acionar a relação entre artes cênicas e pedagogia em perspectiva anti-colonial, desenvolvidas junto a jovens estudantes da Escola Estadual Indígena de Ensino Médio Pascoal Leite Dias situada na Terra Indígena Terena Limão Verde (Aquidauana/MS) onde realizei uma residência artístico-pedagógica chamada "Nós somos a crise", contemplada pelo Prêmio Mais Cultura nas Escolas (MinC/MEC), entre agosto de 2014 e junho de 2016.

Não me aterei em descrever todo este processo de dois anos, mas apenas em mostrar, resumidamente, alguns de seus resultados.

Em 11 de novembro de 2015 foi organizada pela Articulação dos Povos Indígenas do Brasil mais uma Mobilização Nacional Indígena contra a Proposta de Emenda Constitucional 215/20019, através de atos realizados em todo o país. Em apoio, o professor de história e sociologia da escola, Hanaiti Kaxe, realizou junto aos estudantes, uma ação-imagem em apoio a esta mobilização nacional. Esta imagem chegou a mim no meu feed de notícias da rede social Facebook via compartilhamento da mesma pela página pessoal do Facebook do referido professor.

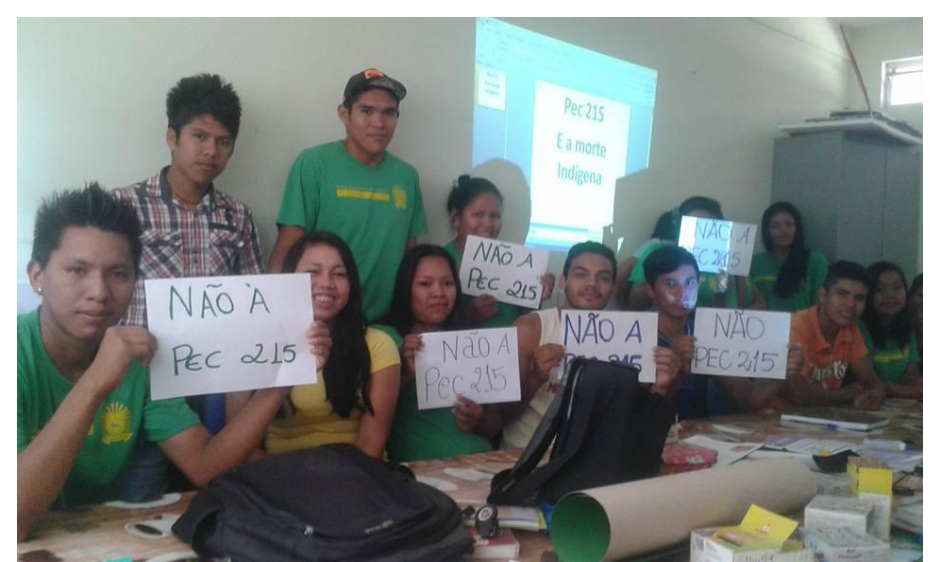

Estudantes da Escola Estadual Indígena de Ensino Médio Pascoal Leite Dias.

Fotografia: Hanaiti Kaxe

\footnotetext{
8 Um dos produtos audiovisuais desta residência pode ser visto através do enlace eletrônico disponível em: https://www.youtube.com/watch?v=hd8IXONWRps\&t=32s. Acesso em: 28/02/2018.

9 Em linhas gerais, a Proposta de Emenda Constitucional 215 propõe que a demarcação de terras (indígenas, quilombolas, etc.) no país passasse da União para o Congresso Nacional, possibilitando a revisão de terras já demarcadas, além da criação de novos critérios e procedimentos para a demarcação de novas terras. Segundo vários setores indigenistas, a proposta é inconstitucional e fere direitos fundamentais dos povos originários em prol do fortalecimento do agronegócio brasileiro, suportado pela bancada ruralista dentro da Câmara dos Deputados.
} 
À época eu estava desenvolvendo a pesquisa que desembocou na minha dissertação de mestrado intitulada "Nós fizemos isso para vocês, brancos, saberem que nós existimos!": imagens de luta dos povos originários do Brasil (2013-2015). Tal dissertação apresentou um arquivo com imagens fotográficas de ações simbólicas, que envolvem algum tipo de representação, realizadas pelos povos originários do Brasil em situação de luta contra a colonização ainda vigente, expresso à época, especialmente, na Proposta de Emenda Constitucional 215 (PEC 215), do ex-deputado Almir Sá. Estas imagens foram tão somente conhecidas e recolhidas por mim no espectro do ativismo virtual e sua seleção foi orientada pela pergunta: como os povos originários do Brasil refuncionalizam as ferramentas de agitação e propaganda disponíveis?

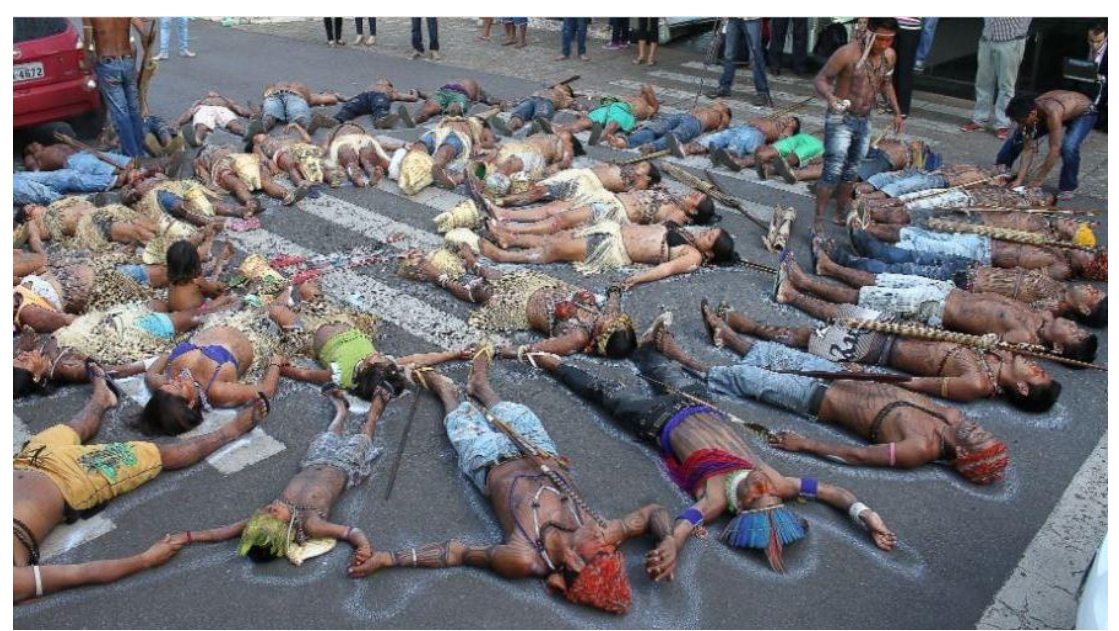

Índios mundurucus e caiapós protestam contra a construção da usina de Belo Monte em frente ao STF (Supremo Tribunal Federal), em Brasília. Na sequência, eles fizeram uma caminhada pela Esplanada dos Ministérios até o Palácio do Planalto (Brasília, 11 de junho de 2013). Fotografia: André Borges/UOL

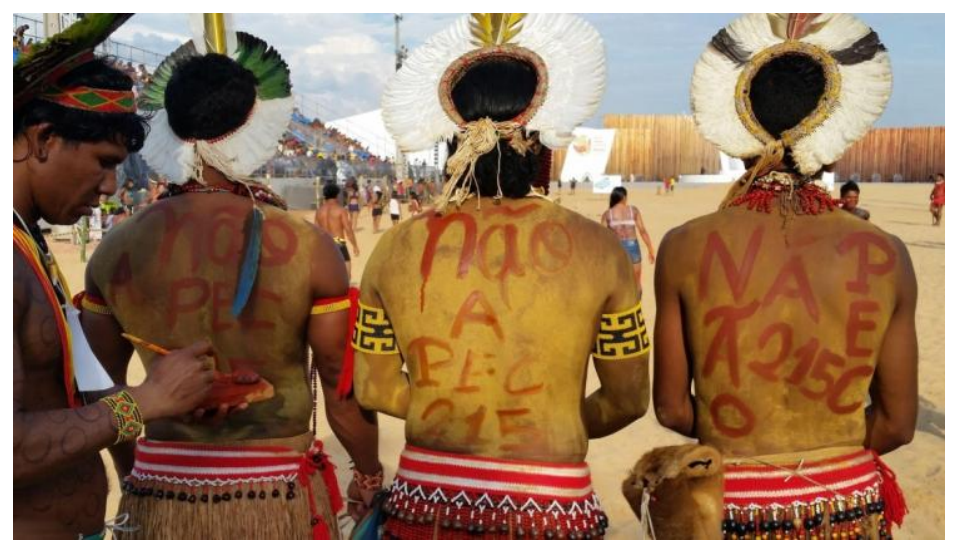

Pintura corporal durante os Jogos Mundiais dos Povos Indígenas (Palmas/TO, outubro de 2015). Fotografia: Marcelo Camargo/Agência Brasil 


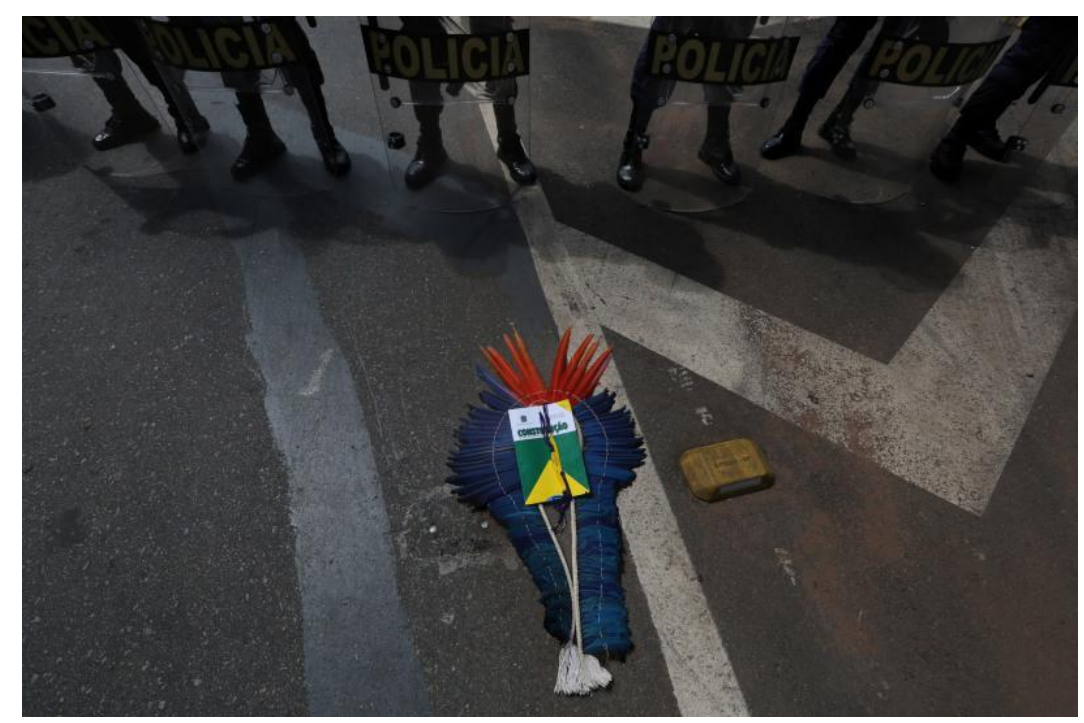

Manifestação indígena (Brasília, abril de 2015). Fotografia: Lunaé Parracho/MNI

Assim, tendo em vista o desejo e já uma recente produção de imagens para circulação na rede virtual que expressou o repúdio de estudantes e professores contra a PEC 215, propus ao professor Hanaiti e aos jovens estudantes que realizássemos uma nova produção de imagens para circulação virtual, mas agora, em apoio e conectada à agenda de luta indígena nacional que estava concentrada nesse momento no XIII Acampamento Terra Livre (ATL) - encontro entre diversos povos originários realizado entre 10 e 13 de maio de 2016, em Brasília.

Nossa fonte de inspiração seriam as diversas imagens que eu vinha coletando na referida pesquisa de mestrado. Assim, vimos juntos, com a ajuda de um projetor, as imagens e discutimos cada uma delas. A discussão sobre as imagens foi, sobretudo, mediada por Hanaiti que esteve em diversos atos e manifestações pelos direitos dos povos originários tanto em Brasília quanto em outras localidades do Brasil e que inclusive presenciou corporalmente muitas das ações-imagens que vimos juntos.

Depois dessa etapa de conhecer a produção simbólica atual de vários povos originários do Brasil em situação de luta pelos seus direitos também originários, nos dividimos em três grupos, entre estudantes e professores e, inspirados pelas imagens que tínhamos acabado de ver e discutir, propus que criássemos (dialogando com essas imagens, criando a partir delas) nossas próprias imagens, a partir de nossas condições e inquietações, em apoio ao Acampamento Terra Livre e de contra ao sistema político colonial que nos prejudica a todos. 
Vale dizer que desde o início foi acordado que faríamos juntos a escolha das imagens, depois da sessão de fotos, que circulariam na internet como forma de apoio e conexão, ainda que virtual, à luta que estava sendo realizada em todo Brasil.
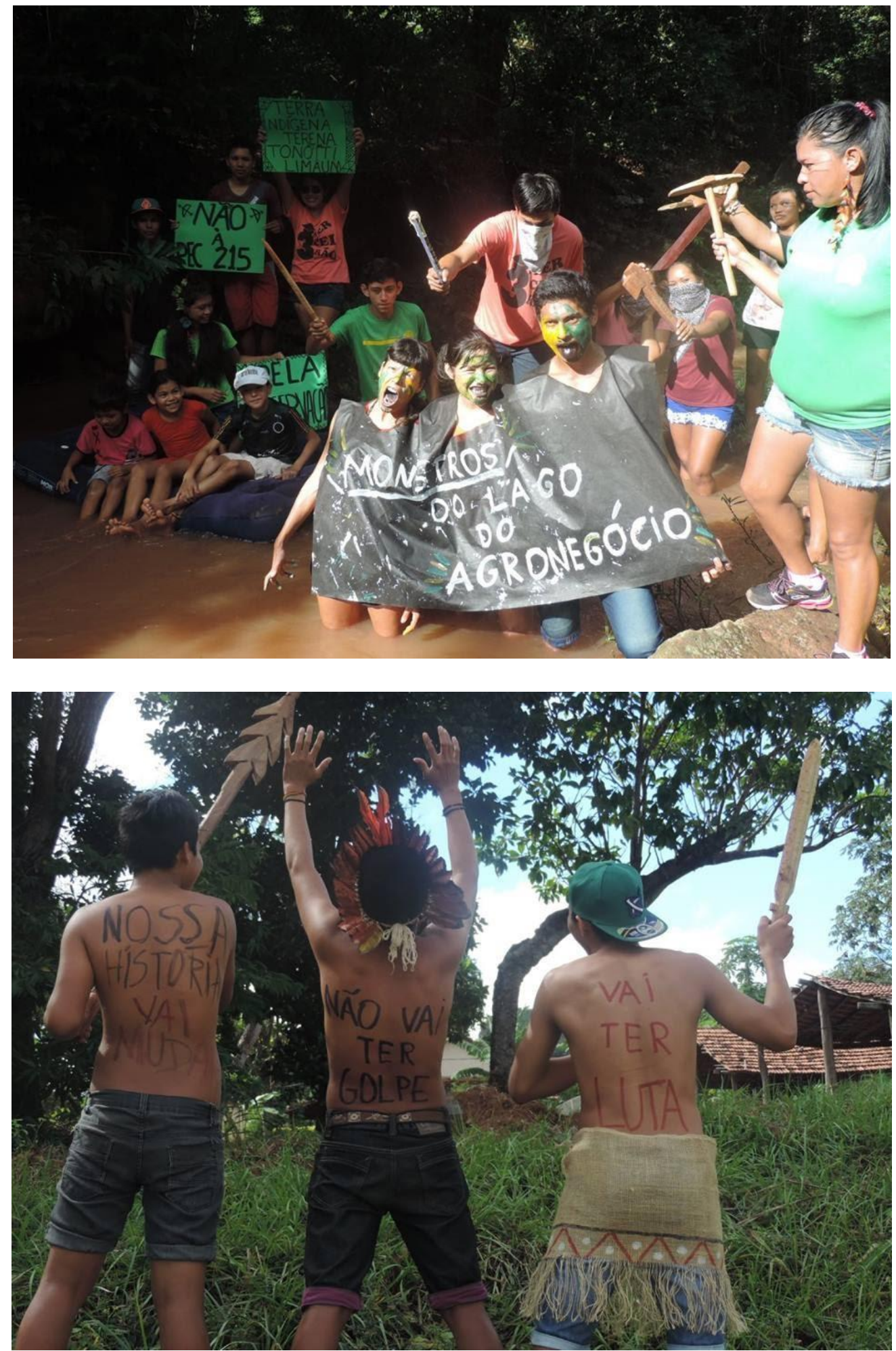

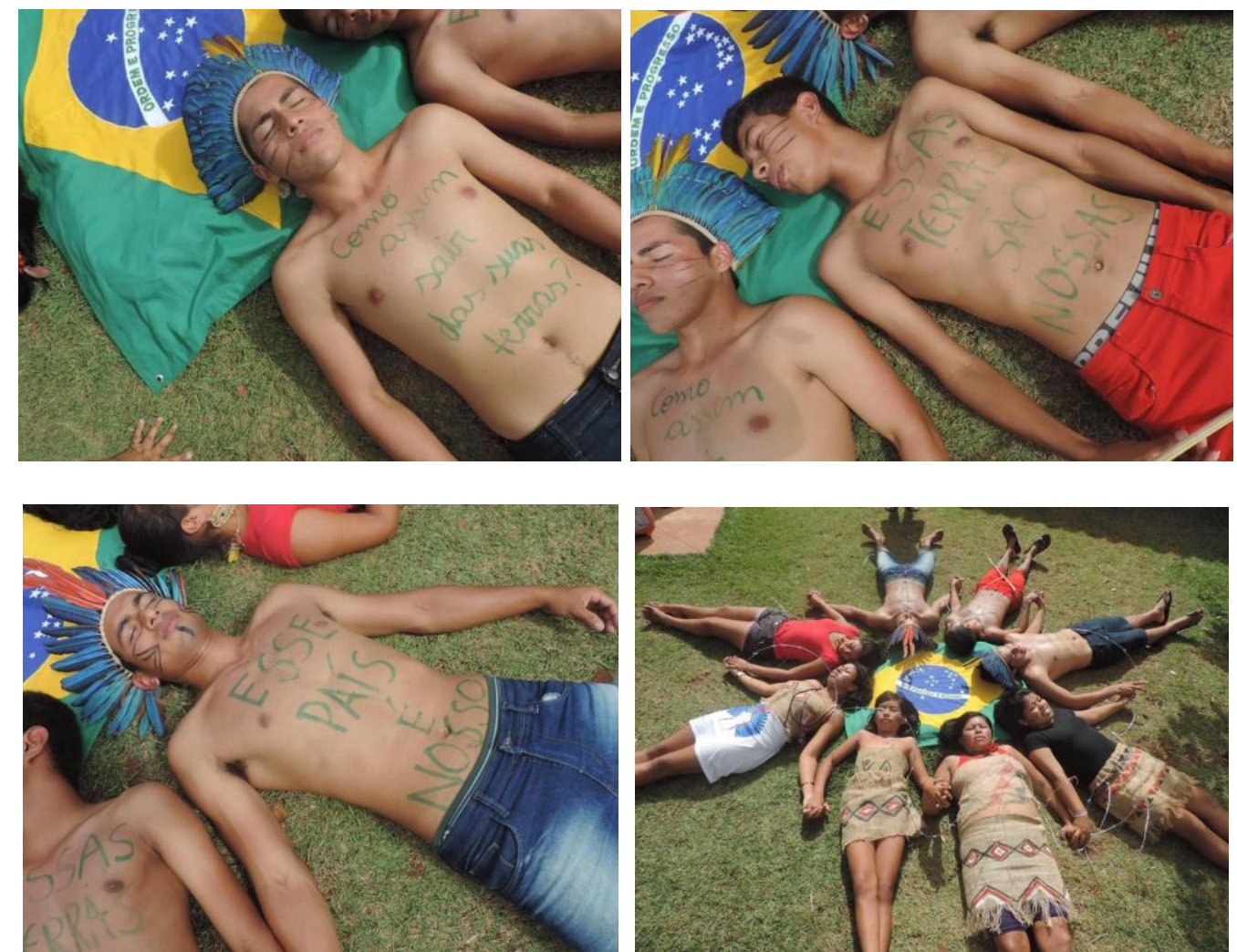

Estudantes da Escola Estadual Indígena de Ensino Médio Pascoal Leite Dias. Fotografia: Sandriane Soares de Souza

Como Hanaiti é militante indígena e colaborador da Rádio Yandé, a primeira rádio online indígena do Brasil e eu, por conta da minha militância, tenho agregados ao meu perfil do Facebook várias páginas e perfis ligados à luta indígena e ao ativismo virtual do mesmo, enviamos essas imagens para tais redes de difusão de imagens e informações (além de as compartilharmos em nossos perfis individuais e no perfil da escola). Então, tais imagens circularam na rede virtual na semana que seguiu o ATL: 

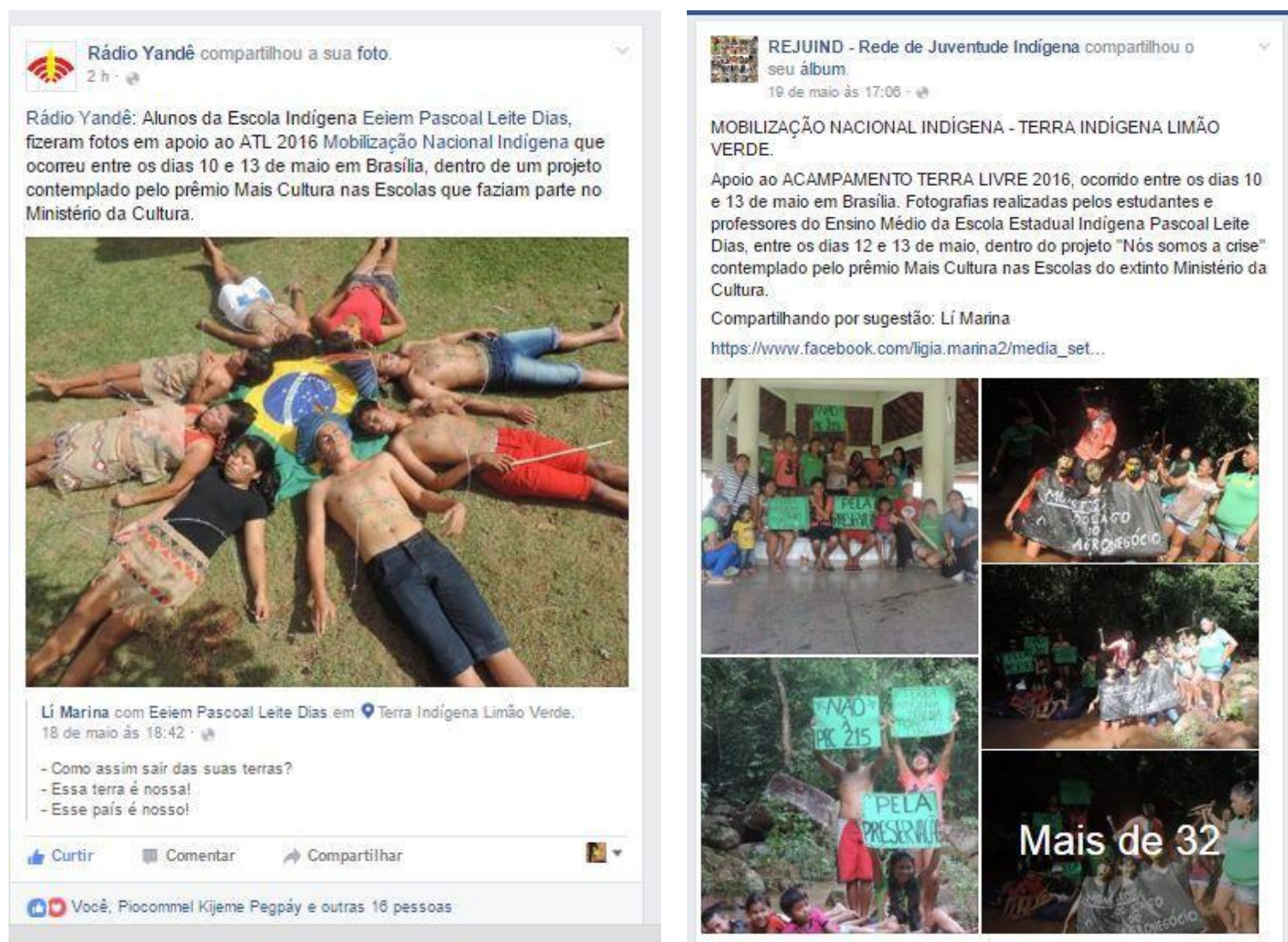

Circulação no Facebook das imagens produzidas na Terra Indígena Limão Verde em apoio ao ATL/2016.

A proposta é que o apoio a uma determinada luta, através de um meio técnico que desmaterializa os corpos, seja pela sobrevivência real de seus próprios corpos.

A proposta é que exista a possibilidade de nos inspirarmos e refuncionalizarmos "tecnicamente" em outras propostas, corporalidades, existências e práticas "cênicas" que não apenas eurocentradas ou estadunidense.

A proposta é apresentar possibilidades de outras ações artístico-pedagógicas para o campo da pedagogia das artes cênicas.

Creio que esta pequena metodologia aqui apresentada possa vir a contribuir para esta perspectiva ao apresentar caminhos e ferramentas disponíveis a qualquer artista-docente que queira atuar junto à Lei 11.645/2008, com público indígena o nãoindígena, na perspectiva que apresentou Jerá Poty na relatada palestra no MASP: aprender a aprender com a luta, simbólica e real, dos povos originários pela descolonização social. Por uma melhor existência entre a terra, humanes e nãohumanes. 


\section{REFERÊNCIAS}

ALMEIDA, Lígia Marina de. "Nós fizemos isso para vocês, brancos, saberem que nós existimos!': imagens de luta dos povos originários do Brasil (2013-2015). Universidade do Estado de Santa Catarina, Centro de Artes, Mestrado em Teatro, Florianópolis, 2016.

BENJAMIN, Walter. Magia e técnica, arte e política. Tradução de Sérgio Paulo Rouanet. São Paulo: Brasiliense, 1994.

BRANCO, João Francisco Migliari. Movimento Docente, Insurreição Popular e Propostas Coletivas de Educação Alternativa em Oaxaca. Dissertação (Mestrado em Educação) - Faculdade de Educação, Universidade de São Paulo, São Paulo, 2015

COMISSÃO GUARANI YVURUPA. Manifesto: porque fechamos a bandeirantes? 2013. Disponível em: $<$ https://www.youtube.com/watch?v=eV7WMdvGirM $>$. Acesso em 19/07/16.

TIBLE, Jean. Marx selvagem. São Paulo: Annablume, 2013.

TUPINAMBÁ, Casé Angatú Xukurú. "Histórias e culturas indígenas"- alguns desafios no ensino e na aplicação da lei 11.645/2008: de qual história e cultura indígena estamos mesmo falando? Disponível em: http://www.seer.ufu.br/index.php/historiaperspectivas/article/viewFile/32772/17715. Acesso em 03/08/17.

Recebido em agosto de 2018. Aprovado em outubro de 2018. Publicado em dezembro de 2018. 